\title{
Comparison of Infusions from Black and Green Teas (Camellia sinensis L. Kuntze) and Erva-mate (Ilex paraguariensis A. St.-Hil.) Based on the Content of Essential Elements, Secondary Metabolites, and Antioxidant Activity
}

\author{
Pawel Konieczynski $^{1}$ - Agnieszka Viapiana ${ }^{1} \cdot$ Marek Wesolowski $^{1}$ \\ Received: 26 October 2016 / Accepted: 10 March 2017 /Published online: 24 March 2017 \\ (C) The Author(s) 2017. This article is published with open access at Springerlink.com
}

\begin{abstract}
The aim of the research was to compare chemical composition and antioxidant activity of black and green teas with those of erva-mate. Therefore, essential elements $(\mathrm{P}, \mathrm{Mg}$, $\mathrm{Fe}, \mathrm{Zn}, \mathrm{Mn}$, and $\mathrm{Cu}$ ), phenolic acids (gallic, caffeic, $p$ coumaric, and ferulic), flavonoids (catechin, rutin, myricetin, apigenin, and quercetin), and alkaloids (caffeine, theobromine, and theophylline) were determined. Phenolics and alkaloids were quantified by HPLC, metallic elements by atomic absorption spectrometry, and antioxidant activity by a $2,2^{\prime}-$ azino-bis(3-ethylbenzthiazoline)-6-sulfonic acid method. Total $\mathrm{P}$, inorganic $\mathrm{P}$, and $\mathrm{Mg}$ expressed in milligrams per gram dry weight (d.w.) and other metals expressed in milligrams per kilogram d.w.) in the order $\mathrm{Mn}>\mathrm{Zn}>\mathrm{Fe}>\mathrm{Cu}$ were assayed. Caffeine was found above $25 \mathrm{mg} / \mathrm{g}$ d.w. in all samples. Among the phenolic compounds, caffeic acid and quercetin were on the highest level, whilst apigenin and $p$-coumaric acid were on the lowest. Correlation analysis revealed frequently occurring relations between $\mathrm{P}$ and several metals and phenolics and also between $\mathrm{Zn}$ and other metabolites from flavonoids, phenolic acids, and alkaloids. Within organic compounds, correlations were often found among gallic and caffeic acids and other analytes, like $p$-coumaric, ferulic acids, and myricetin. Antioxidant activity of studied infusions from different types of teas was very similar. Cluster analysis grouped the studied materials into clear clusters, generally separating erva-mate samples from Camellia sinensis. Principal component analysis indicated total $\mathrm{P}, \mathrm{Mg}, \mathrm{Cu}$,
\end{abstract}

Pawel Konieczynski

pawelkon@gumed.edu.pl

1 Department of Analytical Chemistry, Medical University of Gdansk, Gen. J. Hallera 107, 80-416 Gdansk, Poland caffeic acid, myricetin, and $p$-coumaric acid as factors influencing mostly the diversity among analyzed samples.

Keywords Camellia sinensis (L.) Kuntze $\cdot$ Ilex paraguariensis A. St.-Hil. · Essential elements · Secondary metabolites $\cdot$ Antioxidant activity

\section{Introduction}

Infusions prepared from green and black teas (Camellia sinensis (L.) Kuntze) have become very popular beverages among populations of many countries worldwide. Main exporters of tea are China, India, Turkey, Iran, and other Southern Asian countries (Salahinejad and Aflaki 2010). Beneficial effects of tea drinking for human health are numerous, including, for example, its stimulating influence on the brain; protective action against various types of cancers, like lung, prostate, and breast tumors; reduction of cholesterol levels in the blood; and also boosting the immune system. This positive impact on the human organism is caused by antioxidant properties of polyphenolic compounds that are present in tea infusions, among them phenolic acids (Ronowicz et al. 2014; Salahinejad and Aflaki 2010). Other chemical constituents in $C$. sinensis tea consist of volatile compounds, alkaloids, vitamins, carbohydrates, amino acids, proteins, chlorophyll, fluoride, minerals, and trace elements (Carbera et al. 2003). Polyphenols are compounds of great interest because they have potent antioxidant activity both in vitro and in vivo due to its reducing properties ( $\mathrm{Wu}$ and Wei 2002). Among flavonoids, quercetin and myricetin are observed in considerable quantities in tea of $C$. sinensis (Saito and Miyata 2000).

However, especially in Southern America societies, common infusions of erva-mate in Brazil, also known as yerba- 
mate in Spanish language countries, are consumed. Erva-mate is a traditional beverage drunk by South American cowboys (gauchos) and is obtained from a shrub, Ilex paraguariensis A. St.-Hil. After Paraguay, Brazil is the second producer of erva-mate in the world (Neto et al. 2007). Methylxanthines, represented by caffeine, are among the compounds present in erva-mate (Bojic et al. 2013). Moreover, infusions prepared from erva-mate can influence human well-being; for instance, they can stimulate antirheumatic and anti-inflammatory and diuretic activities (Jacques et al. 2007).

Due to high consumption of these beverages worldwide, there are many studies, in which the chemical composition of tea and erva-mate infusions was examined. For example, the chemical composition of erva-mate samples was studied in order to detect differences in the level of essential elements in the samples harvested in seven locations in Southern Brazil (Reissmann et al. 1999). Toxic and nutrient elements were analyzed by ICP-OES in samples of erva-mate from different countries (Argentina, Brazil, Paraguay, and Uruguay) (Pozebon et al. 2015). Erva-mate infusions were also analyzed in order to detect differences in fluoride contents in samples originating from various countries (Lukomska et al. 2015).

Green tea leaves from $C$. sinensis among other herbal teas obtained from peppermint, Echinacea, red clover, Siberian ginseng, dandelion, red raspberry, and blueberry leaves were also investigated (Gallaher et al. 2006). Mineral contents of teas from several botanical species available in Brazil were also analyzed by XRF spectrometry (Wastowski et al. 2013).

Mineral composition, including assays of micro- and macro-elements in herbal teas obtained from mint and mixture of chamomile and lavender leaves, was studied, and it was found that metal bioavailability was significantly different depending on the element analyzed (Szymczycha-Madeja et al. 2013). Recently, the effect of the origin of medicinal herbs from distant regions of Europe on the contents of essential elements in infusions obtained from them was investigated (Konieczynski et al. 2016).

Taking all the above into account, the commercially available samples of tea (black, green) and erva-mate from different regions of the world were studied regarding their mineral and secondary plant metabolites (phenolics and alkaloids) and antioxidant activities. In the work, flame atomic absorption spectrometry (FAAS) was used to determine metallic essential elements ( $\mathrm{Fe}, \mathrm{Mg}, \mathrm{Zn}, \mathrm{Mn}$, and $\mathrm{Cu}$ ), HPLC-UV for phenolic compounds (gallic, caffeic, $p$-coumaric, and ferulic acids; rutin; myricetin; quercetin; apigenin; and catechin), and alkaloids (theobromine, theophylline, and caffeine), and UV/Vis spectrophotometry for determination of antioxidant activity (2,2'-azino-bis(3-ethylbenzthiazoline)-6-sulfonic acid, ABTS), total phosphorus (P), and $\mathrm{P}_{-} \mathrm{PO}_{4}$. In order to detect similarities and differences among the studied tea and ervamate samples, multivariate methods, such as cluster and principal component analyses, were applied.

\section{Materials and Methods}

\section{Tea Material and Sample Preparation}

The samples of tea and erva-mate under analysis are listed in Table 1. The infusions were prepared by pouring boiling redistilled water $(100 \mathrm{~mL})$ into $1.0 \mathrm{~g}$ of a tea material. After 20 min of brewing under cover, infusions were filtered through paper filters (Filtrak No. 389, Germany) and diluted to $100 \mathrm{~mL}$ using redistilled water, obtained in a Heraeus (Switzerland) distillation system.

Prior to HPLC analysis, the infusions were filtered through a 0.20 - $\mu$ m nylon membrane filter (Witko, Łódź, Poland) into a HPLC vial. For each tea sample, the completed procedure was repeated in triplicate.

\section{Reagents}

Standards of four phenolic acids [gallic acid (GA), caffeic acid (CA), $p$-coumaric acid ( $p$-CA), and ferulic acid (FA)], five flavonoids [catechin (CAT), rutin (RUT), quercetin (QUE), myricetin (MYR), and apigenin (API)], and three alkaloids [theobromine (TBR), theophylline (TPI), and caffeine (CAF)] were purchased from ChromaDex (CA, USA). HPLC grade methanol was obtained from POCh (Gliwice, Poland), and trifluoroacetic acid (TFA) was from SigmaAldrich (St. Louis, MO, USA).

\section{Phosphorus Determinations}

Total and extractable phosphorus were determined using the phosphate-molybdate complex $(\lambda=650 \mathrm{~nm})$ (Konieczynski et al. 2016). Absorbance was measured using a Metertech SP870 (South Korea) UV/Vis spectrometer.

\section{ABTS Radical Scavenging}

The antioxidant capacity on ABTS was assessed by adapting the method described by Re et al. (1999). A solution of $55 \mu \mathrm{M}$ ABTS was prepared in $10 \mathrm{mM}$ phosphate buffer ( $\mathrm{pH} 7.0$ ), and infusions were diluted (1:1, 1:10, and 1:100) with water. The tests were performed by adding three different volumes of each diluted sample $(10,25$, and $50 \mu \mathrm{L})$, ABTS solution $(500 \mu \mathrm{L})$, and phosphate buffer to a final volume of $1 \mathrm{~mL}$. The absorbance was taken after $30 \mathrm{~min}$ at $734 \mathrm{~nm}$, and antioxidant activity was expressed by half maximal inhibitory concentration (IC50) values.

\section{Essential Element Determination}

Essential metallic elements in infusions were assayed using standard analytical conditions (air/acetylene), by a flame atomic absorption spectrometer (250 Plus; Varian, 
Table 1 Studied plant material

\begin{tabular}{|c|c|c|c|c|c|}
\hline No. & Studied material & Botanical plant species & $\begin{array}{l}\text { Country of } \\
\text { origin }\end{array}$ & Company (manufacturer) & Importer \\
\hline EM1 & $\begin{array}{l}\text { Erva-mate } \\
\quad \text { (yerba mate) }\end{array}$ & $\begin{array}{l}\text { Ilex paraguariensis } \\
\text { St.-Hil. }\end{array}$ & Brazil & $\begin{array}{l}\text { Chimarrão Dos Pampas, Fernandes } \\
\text { Pinheiro, PR }\end{array}$ & Leão Junior S.A., Brazil \\
\hline EM2 & & & Argentina & $\begin{array}{l}\text { Taragui Sin Palo, Establecimiento } \\
\text { Las Marias }\end{array}$ & $\begin{array}{l}\text { Oranżada Robert Denatka, } \\
\text { Otwock, Poland }\end{array}$ \\
\hline EM3 & & & Argentina & $\begin{array}{l}\text { Union Suave, Establecimiento } \\
\text { Las Marias }\end{array}$ & \\
\hline GT4 & Green tea & $\begin{array}{l}\text { Camellia sinensis (L.) } \\
\text { Kuntze }\end{array}$ & China & Chinese company & $\begin{array}{l}\text { BiFIX W. Piasecki Sp. j. } \\
\text { Górki Małe, Poland }\end{array}$ \\
\hline GT5 & & & China & Chinese company & "Jahmajka" Sopot, Poland \\
\hline GT6 & & & Japan & Japanese company & \\
\hline BT7 & Black tea & $\begin{array}{l}\text { Camellia sinensis (L.) } \\
\text { Kuntze }\end{array}$ & Sri Lanka & MUF Holdings, Ltd. & $\begin{array}{l}\text { Gourmet Foods, Sp. z o.o., } \\
\text { Warszawa, Poland }\end{array}$ \\
\hline BT8 & $\begin{array}{l}\text { Black tea "Tippy } \\
\text { Milima" }\end{array}$ & & Kenya & Kenyan company & "Jahmajka" Sopot, Poland \\
\hline BT9 & Black tea Darjeeling & & India & Teesta Valley & \\
\hline BT10 & Black tea & & China & Yunnan & \\
\hline BT11 & Finest Oolong & & $\begin{array}{l}\text { China, } \\
\text { Taiwan }\end{array}$ & Chinese company & \\
\hline
\end{tabular}

Australia), and the appropriate analytical wavelengths (nm) were $285.2(\mathrm{Mg}), 248.3(\mathrm{Fe}), 213.9(\mathrm{Zn}), 279.5(\mathrm{Mn})$, and $324.8(\mathrm{Cu})$. The tea and erva-mate samples were diluted 100 times before $\mathrm{Mg}$ determination, and to each diluted sample, $1 \%$ solution of $\mathrm{La}_{2} \mathrm{O}_{3}$ was added prior to measurement by FAAS. The analytical procedures used in the study have been validated recently, and the obtained data of linearity, accuracy, recovery, LOD, and LOQ were satisfactory (Konieczynski et al. 2015, 2016).

\section{Secondary Metabolites Determinations}

Phenolic compounds were determined using a HPLC LaChrom (Merck, Darmstadt, Germany) system consisting of L-7100 pump, L-7360 column compartment, and L-7420 UV detector. The separation was performed on a Hypersil Gold C18 column $(250 \times 4.6 \mathrm{~mm}, 5-\mu \mathrm{m}$ particles) (Thermo Scientific, Runcorn, UK), maintained at $30{ }^{\circ} \mathrm{C}$ using methanol- $0.1 \%$ TFA solution (solvent $\mathrm{A}$ ) and water-0.1\% TFA solution (solvent B) as mobile phase. The HPLC mobile phase was prepared fresh daily, filtered through a $0.45-\mu \mathrm{m}$ membrane filter, and then degassed before injection. A gradient program was chosen as follows: 0-40 min, linear 5-25\% A; 40-50 min, linear 25-35\% A; 50-55 min, isocratic $35 \% \mathrm{~A}$; 55-60 min, linear 35-65\% A; and 60-70 min, linear 65-5\% A. The flow rate of mobile phase was $1.0 \mathrm{~mL} / \mathrm{min}$ with an injection volume of $20 \mu \mathrm{L}$, and the runs were monitored at 280, 320, and $370 \mathrm{~nm}$ for benzoic and cinnamic acid derivatives, and flavonoids, respectively. The phenolic compounds and alkaloids were characterized according to their retention time and comparison with standards.
For quantitative analysis, a 6-point calibration curve was obtained by injection of known concentrations of different standards compounds: GA $(10-130 \mu \mathrm{g} / \mathrm{mL}$; $\left.y=44,647 x-221,211 ; R^{2}=0.9960\right), \mathrm{CA}(10-130 \mu \mathrm{g} / \mathrm{mL}$; $\left.y=80,278 x+1673 ; R^{2}=0.9980\right), p-\mathrm{CA}(10-130 \mu \mathrm{g} / \mathrm{mL}$; $\left.y=11,320 x-135,814 ; R^{2}=0.9950\right)$, FA $(10-130 \mu \mathrm{g} / \mathrm{mL}$; $\left.y=119,637 x+818,017 ; R^{2}=0.9960\right)$, CAT $(10-130 \mu \mathrm{g} / \mathrm{mL}$; $\left.y=4327 x+8602 ; R^{2}=0.9980\right)$, RUT $(10-130 \mu \mathrm{g} / \mathrm{mL}$; $\left.y=72,071 x+554,160 ; R^{2}=0.9890\right)$, MYR $(10-130 \mu \mathrm{g} /$ $\left.\mathrm{mL} ; y=12,740 x-2726 ; R^{2}=0.9970\right)$, QUE $(40-200 \mu \mathrm{g} /$ $\left.\mathrm{mL} ; y=12,372 x-230,867 ; R^{2}=0.9985\right)$, API $(10-130 \mu \mathrm{g} /$ $\left.\mathrm{mL} ; y=34,654 x+19,888 ; R^{2}=0.9970\right)$, TBR $(40.32$ $\left.201.16 \mu \mathrm{g} / \mathrm{mL} ; y=131,645 x-61,751 ; R^{2}=0.9951\right)$, TPI (40.53-202.66 $\mu \mathrm{g} / \mathrm{mL} ; y=44,505 x-654,602$; $\left.R^{2}=0.9983\right)$, and CAF $(40-200 \mu \mathrm{g} / \mathrm{mL}$; $\left.y=72,600 x-1,777,442 ; R^{2}=0.9926\right)$.

\section{Statistical Calculations}

All the assays were carried out in triplicate, and the results are expressed in milligrams per gram of dry weight (d.w.) as mean values \pm standard deviation (SD). Analysis of variance (ANOVA) test, followed by Tukey's and Duncan's tests, was performed to check significant differences between samples. A Pearson correlation was used to assess the relationship between metals, phenolics, alkaloids, and antioxidant activity. Calculations were performed using Statistica 10 software (StatSoft, Inc., USA) on the basis of parametric tests with the level of significance of $p<0.05$. Moreover, principal component analysis (PCA) and cluster analysis (CA) were used to interpret the obtained results. 


\section{Results and Discussion}

\section{Essential Elements}

The concentration of total $\mathrm{P}$ was found in the range from 1.06 to $2.87 \mathrm{mg} / \mathrm{g}$ d.w. and that of its water-extractable inorganic form $\left(\mathrm{P}_{\mathrm{i}}\right)$ from 0.38 to $1.17 \mathrm{mg} / \mathrm{g}$ d.w., as shown in Table 2 . Total $\mathrm{P}$ was assayed in higher amounts in green and black tea leaves than that determined in erva-mate samples. On the other hand, $P_{i}$ level was higher in black tea and erva-mate samples originating from Brazil (EM1).

Magnesium was determined in all studied tea and ervamate samples in the similar range of concentrations, from $1.06 \mathrm{mg} / \mathrm{g}$ d.w. in case of green tea (GT4) to $2.14 \mathrm{mg} / \mathrm{g}$ d.w. in black tea (BT9). It can be noticed that $\mathrm{Mg}$ level in all ervamate samples is practically the same, about $1.70 \mathrm{mg} / \mathrm{g}$ d.w., slightly higher than its concentration in tea samples. These results are consistent with the data found in the literature (Reissmann et al. 1999; Gallaher et al. 2006; SzymczychaMadeja et al. 2013; Pohl et al. 2016), and the level of P and $\mathrm{Mg}$ determined in the studied samples of teas and erva-mate represents a quite similar level of concentrations.

In Table 2, the results of determinations of microelements $(\mathrm{Fe}, \mathrm{Mn}, \mathrm{Zn}$, and $\mathrm{Cu}$ ) are presented, too. They followed the order $\mathrm{Mn}>\mathrm{Zn}>\mathrm{Fe}>\mathrm{Cu}$. The quantities of metallic elements assayed in the study are in agreement with the values found in other research on tea, erva-mate, or medicinal herb infusions (Pozebon et al. 2015; Polechonska et al. 2015; Salahinejad and Aflaki 2010; Konieczynski et al. 2015, 2016). However, the level of $\mathrm{Zn}$ and $\mathrm{Cu}$ is higher in all erva-mate samples than that determined in black and green teas, as confirmed by post hoc Tukey's test. For Mn and Fe results, differences between the samples of black and green teas, as well as between teas and erva-mate samples under investigation, appeared to be not significant.

\section{Phenolic Compounds and Alkaloids}

Table 3 shows the results of HPLC determination of selected phenolic compounds (namely GA, CA, $p$-CA, and FA), five flavonoids (CAT, RUT, QUE, MYR, and API), as well as three alkaloids (TBR, TPI, and CAF), along with antioxidant activity in the samples of green and black teas and erva-mate. In all samples, CAF is the compound present at a higher concentration (mean concentration is on the level of $34.30 \mathrm{mg} / \mathrm{g}$ d.w.), whilst API and $p$-CA were found at the lowest mean concentration, 1.00 and $0.23 \mathrm{mg} / \mathrm{g}$ d.w., respectively. Among analyzed teas, erva-mate was the poorest in the most compounds, not counting $\mathrm{CA}$, which was found at the highest level $(8.95 \mathrm{mg} / \mathrm{g}$ d.w. $)$. Black teas were the richest in alkaloids, whilst green teas in phenolic compounds, as shown in Fig. 1.

The range of concentrations ( $\mathrm{mg} / \mathrm{g}$ d.w.) of phenolic compounds determined in this investigation is consistent with that

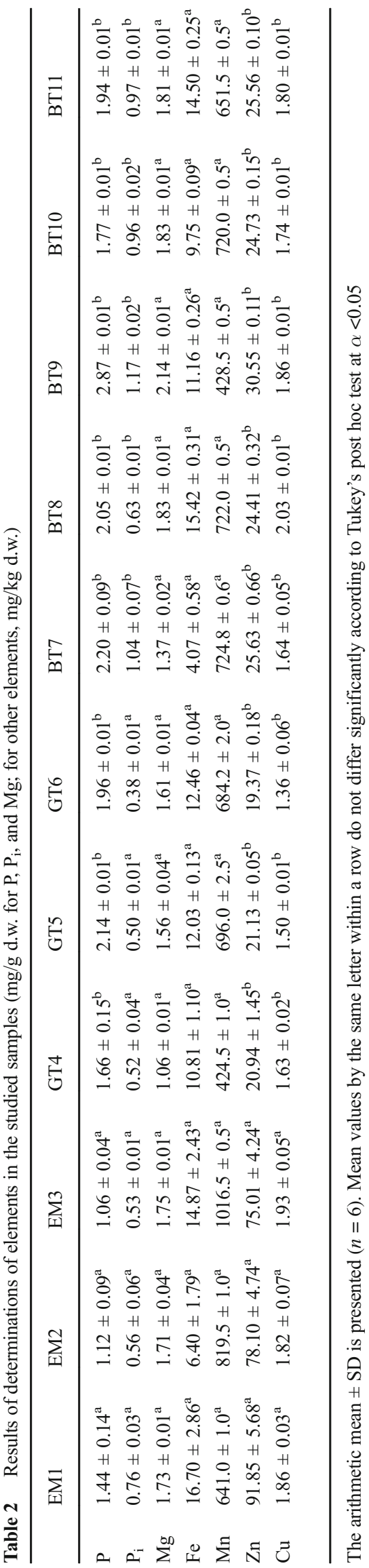




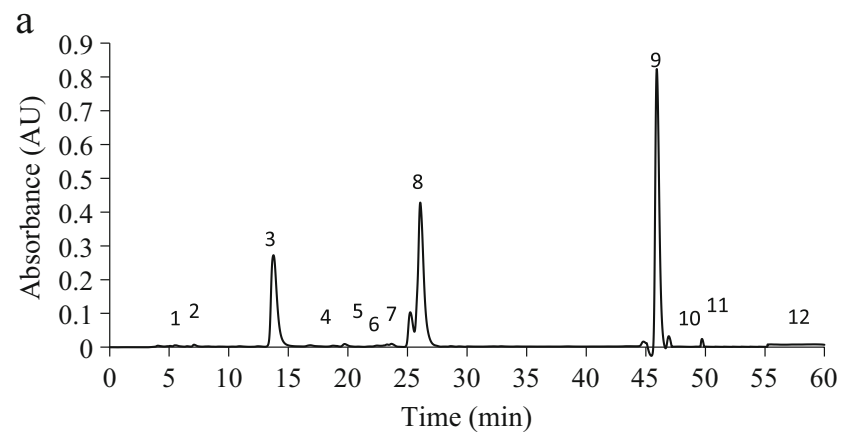

b
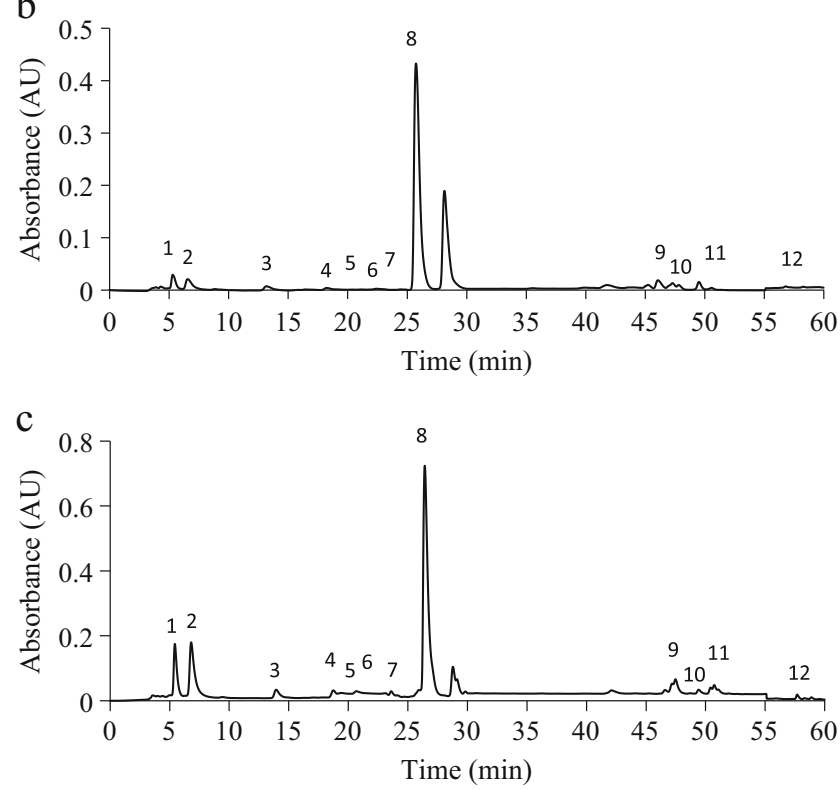

Fig. 1 The HPLC chromatograms of infusions. a Erva-mate. b Green tea. c Black tea. Peak identification: 1 gallic acid, 2 catechin, 3 theobromine, 4 theophylline, $5 p$-coumaric acid, 6 caffeic acid, 7 ferulic acid, 8 caffeine, 9 myricetin, 10 quercetin, 11 rutin, 12 apigenin

reported in the literature concerning studies of phenolics in erva-mate (Bojic et al. 2013) and herbal teas (da Silva Port's et al. 2013). Veljković et al. (2013) determined individual phenols in black and green tea infusions and found that green teas are richer in phenolic compounds than black teas. In the green teas, the mean content of GA, CA, RUT, and CAT was on the level of $1.98,0.261,1.091$, and $0.40 \mathrm{mg} / \mathrm{g}$, respectively, whilst in the black teas, their mean content was on the level of $1.34,0.195,1.485$, and $0.263 \mathrm{mg} / \mathrm{g}$, respectively. The content of RUT is in agreement with that in this study but higher in the case of other analytes obtained in this study. Manchón et al. (2013) determined phenolic compounds and alkaloids in fermented green teas and found GA, CAF, TBR, TPI, and CAT on the same level as in this study, whilst $\mathrm{CA}$ and $p$-CA were on the level below the detection. In unfermented green teas, the concentration of CAT (in the range of 0.29 to $6.28 \mathrm{mg} / \mathrm{g}$ ) was in agreement with that obtained in this study. The level of CAF (from 15.4 to $26.8 \mathrm{mg} / \mathrm{g}$ ) was slightly lower, and the levels of TBR (from 0.40 to 
Table 4 Results of correlation analysis

\begin{tabular}{|c|c|c|c|c|c|c|c|c|c|c|}
\hline & $\mathrm{P}$ & $\mathrm{Fe}$ & $\mathrm{Zn}$ & GA & $\mathrm{CA}$ & $p$-CA & FA & MYR & QUE & IC50 \\
\hline$P_{i}$ & & & & 0.61 & & & & & & \\
\hline $\mathrm{Mg}$ & & & & 0.66 & & & & & & \\
\hline $\mathrm{Mn}$ & -0.63 & & & & & & & & & \\
\hline $\mathrm{Zn}$ & -0.70 & & & & & & & & 0.70 & \\
\hline GA & 0.61 & & & & & & & & & \\
\hline $\mathrm{CA}$ & -0.79 & & 0.71 & -0.82 & & & & & & \\
\hline$p$-CA & 0.62 & & -0.71 & 0.78 & -0.91 & & & & & \\
\hline FA & 0.71 & & -0.70 & 0.73 & -0.86 & 0.95 & & & & \\
\hline MYR & -0.83 & & 0.74 & -0.69 & 0.88 & -0.66 & -0.77 & & & \\
\hline API & & & & -0.61 & 0.61 & & & & & \\
\hline CAT & & & & -0.64 & 0.77 & -0.62 & -0.87 & 0.81 & & \\
\hline CAF & & -0.62 & & & & & & & -0.78 & \\
\hline TBR & -0.72 & & 0.83 & & 0.74 & -0.63 & & 0.73 & & -0.63 \\
\hline
\end{tabular}

The values of statistically significant correlation coefficients are shown in italic font
$2.37 \mathrm{mg} / \mathrm{g}$ ) and GA (from 0.62 to $5.65 \mathrm{mg} / \mathrm{g}$ ) were slightly higher than the results obtained in this work. Lee et al. (2014) determined TBR, CAF, and CAT in green teas and found TBR in the range from 2.83 to $8.81 \mathrm{mg} / \mathrm{g}$, CAF from 26.74 to $29.54 \mathrm{mg} / \mathrm{g}$, and CAT from 0.99 to $2.48 \mathrm{mg} / \mathrm{g}$. These concentrations are slightly lower than those obtained in this study. The differences in phenolic composition could be dependent on biological and environmental factors (Ksouri et al. 2008). Besides, there are different reports of major compound changes in green tea depending on the leaf age (Lee et al. 2014).

\section{Antioxidant Activity}

Antioxidant activity of the studied teas and erva-mate samples was assessed by an ABTS radical scavenging method (Re et al. 1999), and the results expressed as IC50 values are also presented in Table 3. Samples that have lower IC50 values

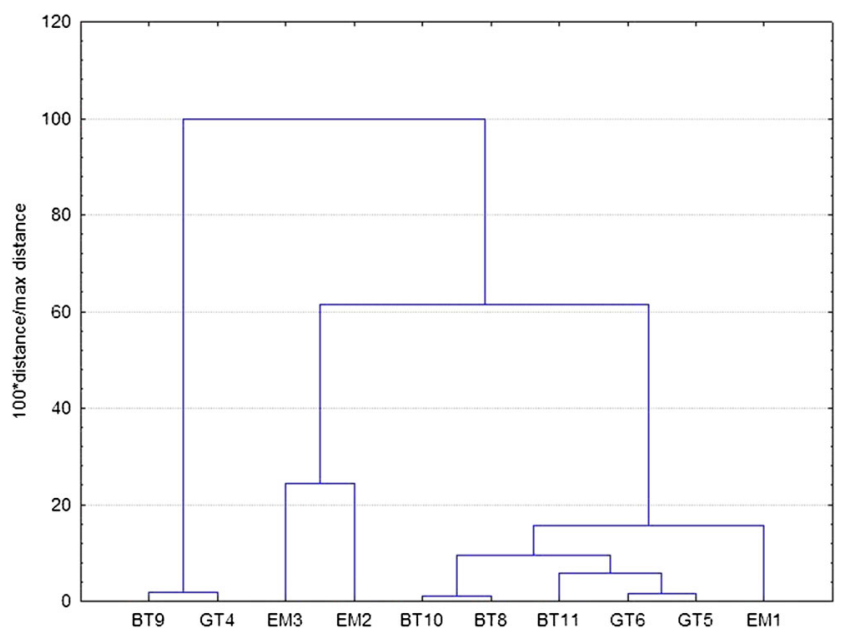

Fig. 2 Results of cluster analysis using the Wards method and Euclidean distance for the studied samples of black and green teas and erva-mate correspond to those that have stronger antioxidant activity. IC50 values showed that antioxidant activities of analyzed infusions from different types of teas are very similar, because the values ranged from $6.41 \mu \mathrm{g} / \mathrm{mL}$ for EM2 to $6.85 \mu \mathrm{g} / \mathrm{mL}$ in the case of BT8. In general, IC50 values represent a slightly higher level than the ones found for tea prepared from I. paraguariensis (Fernandes et al. 2016). These differences can be due to the fact that in this study, aqueous extracts were used to determine antioxidant activity, whereas the other researchers applied ethanolic/aqueous and ethanolic solvents. Comparing the obtained results with those present in the literature, similar IC50 values were obtained by Pereira et al. (2014) for green tea samples, but for black tea samples, these values were slightly higher. In comparison with the IC50 value $(1.10 \mu \mathrm{g} / \mathrm{mL})$ obtained for the standard substance - quercetin - the values of IC50 calculated for the studied samples of teas and erva-mate are about six times higher, which means that they have weaker antioxidant properties than quercetin.

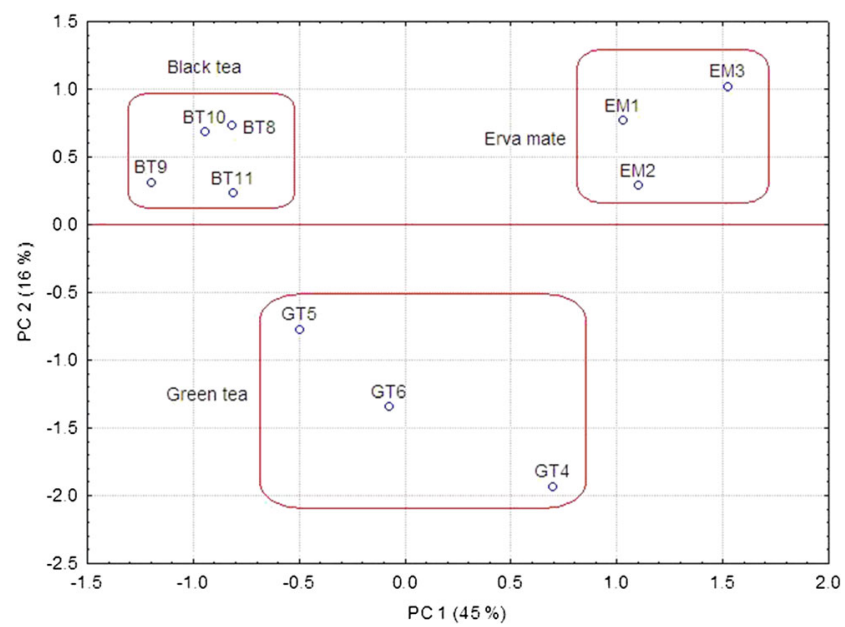

Fig. 3 Scatter plot of black and green tea and erva-mate samples in twodimensional area PC1 vs. PC2 


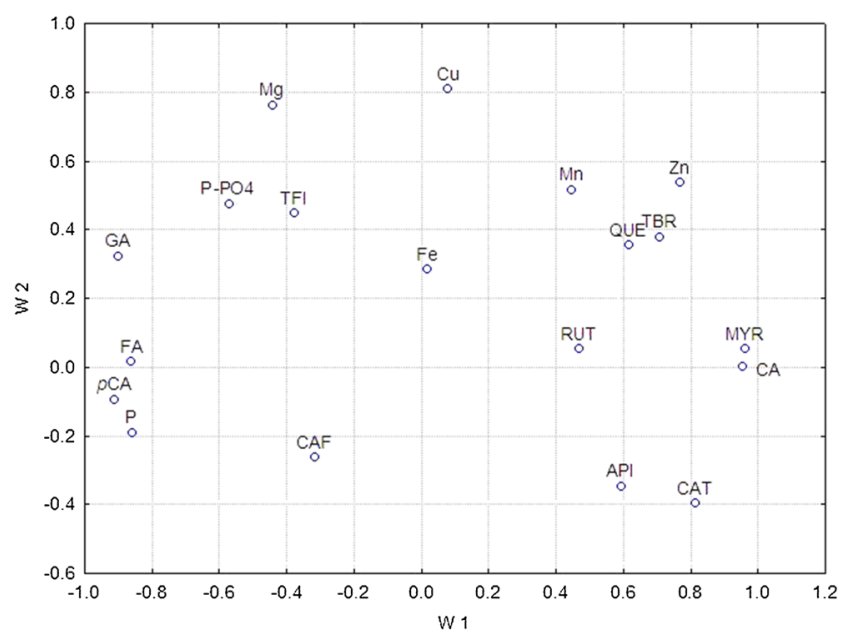

Fig. 4 Loadings of principal components obtained for the studied samples of black and green tea and erva-mate samples

\section{Statistical Evaluation}

Several statistically significant correlations among studied elements, phenolic compounds, alkaloids, and antioxidant activity were revealed (Table 4 ). P correlated with phenolic compounds (GA, CA, $p$-CA, FA, and MYR) and TBR. Zn was related to $\mathrm{CA}, p$-CA, FA, MYR, and CAF. Regarding secondary plant metabolites, significant correlations occurred between GA and elements (Pi, Mg) and other metabolites, like CA, $p$-CA, FA, MYR, API, and CAT. Also, CA was related to $p$-CA, FA, MYR, API, CAT, and TBR. In other cases, only single relations were found, as can be noticed in Table 4 .

In order to detect differences and similarities between the investigated samples as well as to classify them based on the content of elements, phenolic compounds, alkaloids, and antioxidant activity, highly advanced multivariate statistical methods were applied (Otto 2007; Konieczynski et al. 2016). Therefore, dendrogram obtained after calculations of CA using the Wards method and Euclidean distance is shown in Fig. 2. There are clear clusters grouping two samples of erva-mate (EM3 and EM2) in one aggregation in the left part of the plot, and another cluster with the samples of green and black teas can be found in the central and right parts of the plot. However, there are single exceptions from this pattern, like the samples of BT9 and GT4 clustered together in the left side of the dendrogram and one sample of EM1 located in the far right part of the plot. The location of these particular examples can be explained by their different chemical compositions in comparison with the other studied samples of black and green teas or erva-mate.

PCA confirmed these results, and the distribution of the studied samples shown in Fig. 3 clearly indicates all the samples of erva-mate as one group in the right upper corner of the plot, whereas the remaining green and black tea samples are well separated. Two first principal components accounted for
$61 \%$ of the variability among the studied infusions. Moreover, PCA indicated total $\mathrm{P}, \mathrm{Mg}, \mathrm{Cu}, \mathrm{CA}, \mathrm{MYR}$, and $p-\mathrm{CA}$ as factors mostly influencing the diversity among analyzed samples (Fig. 4).

\section{Conclusions}

Based upon the content of essential elements, selected phenolic compounds, alkaloids, and antioxidant activity of black and green tea infusions in comparison with the data obtained for erva-mate, it was possible to distinguish clearly the studied samples. Principal factors, which caused this differentiation between the black and green teas with those of erva-mate, were total $\mathrm{P}$, $\mathrm{Mg}, \mathrm{Cu}, \mathrm{CA}, \mathrm{MYR}$, and $p$-CA. Therefore, it can be stated that the proposed scheme of analysis, including essential elements, phenolics, alkaloids, and antioxidant activity determinations, can be applied for comparison studies of commercially available samples of C. sinensis and erva-mate.

Acknowledgements This paper was supported by the Ministry of Science and Higher Education of the Republic of Poland from the statuary research program (ST-15).

\section{Compliance with Ethical Standards}

Conflict of Interest Pawel Konieczynski declares that he has no conflict of interest. Agnieszka Viapiana declares that she has no conflict of interest. Marek Wesolowski declares that he has no conflict of interest.

Informed Consent Informed consent was obtained from all individual participants for whom identifying information is included in this article.

Ethical Approval This article does not contain any studies with human participants performed by any of the authors.

Open Access This article is distributed under the terms of the Creative Commons Attribution 4.0 International License (http:// creativecommons.org/licenses/by/4.0/), which permits unrestricted use, distribution, and reproduction in any medium, provided you give appropriate credit to the original author(s) and the source, provide a link to the Creative Commons license, and indicate if changes were made.

\section{References}

Bojic M, Haas VS, Saric D, Meles Z (2013) Determination of flavonoids, phenolic acids, and xanthines in mate tea (Ilex paraguariensis St.Hil.) J Anal Methods Chem. doi:10.1155/2013/658596

Carbera C, Gimenez R, Lopez C (2003) Determination of tea components with antioxidant activity. J Agr Food Chem 51:4427-4435

Da Silva Port's P, Chisté RC, Godoy HT, Prado MA (2013) The phenolic compounds and the antioxidant potential of infusion of herbs from the Brazilian Amazonian region. Food Res Int 53:875-881 
Fernandes CEF, Kuhn F, Scapinello J, Lazarotto M, Bohn A, Boligon AA, Athayde ML, Zanatta MS, Zanatta L, Dal Magro J, Oliveira JV (2016) Phytochemical profile, antioxidant and hypolipemiant potential of Ilex paraguariensis fruit extracts. Ind Crop Prod 81:139-146

Gallaher RN, Gallaher K, Marshall AJ, Marshall AC (2006) Mineral analysis of ten types of commercially available tea. J Food Comp Anal 19:S53-S57

Jacques RA, Arruda EJ, de Oliveira LCS, de Oliveira AP, Dariva C, de Oliveira JV, Caramao EB (2007) Influence of agronomic variables on the macronutrient and micronutrient contents and thermal behavior of mate tea leves (Ilex paraguariensis). J Agric Food Chem 55: 7510-7516

Konieczynski P, Arceusz A, Wesolowski M (2015) Relationships between flavonoids and selected elements in infusions of medicinal herbs. Open Chem 13:68-74

Konieczynski P, Arceusz A, Wesolowski M (2016) Essential elements and their relations to phenolic compounds in infusions of medicinal plants acquired from different European regions. Biol Trace Elem Res 170:466-475

Ksouri R, Megdiche W, Falleh H, Trabelsi N, Boulâaba M, Smaoui A, Abdelly C (2008) Influence of biological, environmental and technical factors on phenolic and antioxidant activities of Tunisian halophytes. C R Biol 331:865-873

Lee LS, Kim SH, Kim YB, Kim YC (2014) Quantitative analysis of major constituents in green tea with different plucking periods and their antioxidant activity. Molecules 19:9173-9186

Lukomska A, Jakubczyk K, Maciejewska D, Baranowska-Bosiacka I, Janda K, Goschorska M, Chlubek D, Bosiacka B, Gutowska I (2015) The fluoride content of yerba-mate depending on the country of origin and the conditions of the infusion. Biol Trace Elem Res 167:320-325

Manchón N, Mateo-Vivaracho L, D’arrigo M, Garcia-Lafuente A, Guillamón E, Villares A, Rostagno MA (2013) Distribution patterns of polyphenols and alkaloids in instant coffee, soft and energy drinks, and tea. Czech J Food Sci 31:483-500

Neto JV, Dal'Col Lucio A, Storck L, Chiaradia LA, Sidinei JL (2007) Dinamica populacional do acaro-do-bronzeado na cultura da ervamate em Chapeco, Santa Catarina. Cienc Rural 37:612-617

Otto M (2007) Statistics and computer application in analytical chemistry, 2nd edn. Wiley-VCH, Weinheim

Pereira VP, Knor FJ, Vellosa JCR, Beltrame FL (2014) Determination of phenolic compounds and antioxidant activity of green, black and white teas of Camellia sinensis (L.) Kuntze, Theaceae. Rev Bras Pl Med, Campinas 16:490-498

Pohl P, Dzimitrowicz A, Jedryczko D, Szymczycha-Madeja A, Welna M, Jamroz P (2016) The determination of elements in herbal teas and medicinal plant formulations and their tisanes. J Pharm Biomed Anal. doi:10.1016/j.jpba.2016.01.042

Polechonska L, Dambiec M, Klink A, Rudecki A (2015) Concentrations and solubility of selected trace metals in leaf and bagged black teas commercialized in Poland. J Food Drug Anal 23:486-492

Pozebon D, Dressler VL, Marcelo MCA, de Oliveira TC, Ferrao MF (2015) Toxic and nutrient elements in yerba-mate (Ilex paraguariensis). Food Addit Contam B 8:215-220

Re R, Pellegrini N, Proteggente A, Pannala A, Yang M, Rice-Evans C (1999) Antioxidant activity applying an improved ABTS radical cation decolorization assay. Free Rad Biol Med 26:1231-1237

Reissmann CB, Radomski MI, Bianchini de Quadros RM (1999) Chemical composition of Ilex paraguariensis St. Hil. under different management conditions in seven localities of Parana state. Braz Arch Biol Technol 42:1-7

Ronowicz J, Kupcewicz B, Budzisz E (2014) Implementation of chemometric techniques for evaluation of antioxidant properties of Camellia sinensis extracts. Cent Eur J Chem 12:700-710

Saito T, Miyata G (2000) The nutraceutical benefit. Part I: green tea. Nutrition 16:315-317

Salahinejad M, Aflaki F (2010) Toxic and essential mineral elements content of black tea leaves and their tea infusions consumed in Iran. Biol Trace Elem Res 134:109-117

Szymczycha-Madeja A, Welna M, Zyrnicki W (2013) Multi-element analysis, bioavailability and fractionation of herbal tea products. $\mathrm{J}$ Braz Chem Soc 24:777-787

Veljković JN, Pavlović AN, Mitić SS, Tošić SB, Stojanović GS, Kaličanin BM, Stanković DM, Stojković MB, Mitić MN, Brcanović JM (2013) Evaluation of individual phenolic compounds and antioxidant properties of black, green, herbal and fruit tea infusions consumed in Serbia: spectrophotometrical and electrochemical approaches. J Food Nutr Res 52:12-24

Wastowski AD, Gonsiorkiewicz Rigon JP, Cherubin MR, da Rosa GM, da Silva Bairros PR, Capuani S (2013) Determination of the inorganic constituents of commercial teas and their infusions by the technique of energy dispersive X-ray fluorescence spectrometry. J Med Plants Res 7:179-185

Wu CD, Wei G (2002) Tea as a functional food for oral health. Nutrition 18:443-444 